\title{
Can We Enhance Statistical Learning? Exploring Statistical Learning Improvement in Children with Vocabulary Delay
}

\author{
Dongsun Yima, Yoonhee Yang ${ }^{\mathrm{b}}$ \\ ${ }^{a}$ Department of Communication Disorders, Ewha Womans University, Seoul, Korea \\ ${ }^{b}$ The Special Education Research Institute, Ewha Womans University, Seoul, Korea
}

Correspondence: Dongsun Yim, PhD

Department of Communication Disorders, Ewha Womans University, 52 Ewhayeodae-gil, Seodaemun-gu, Seoul 03760, Korea

Tel: $+82-2-3277-6720$

Fax: +82-2-3277-2122

E-mail: sunyim@ewha.ac.kr

Received: March 22, 2021

Revised: May 9, 2021

Accepted: May 15, 2021
Objectives: If statistical learning ability is critical for language acquisition and language development, it is necessary to confirm whether enhancing statistical learning ability can improve the children's language skills. The present study investigated whether children with and without vocabulary delay (VD) show a difference in improving statistical learning (SL) tasks manipulated with implicit, implicit* 2 and explicit conditions, and with visual and auditory domains; and also explores the relationship among $\mathrm{SL}$, vocabulary, and quick incidental learning (QUIL). Methods: A total of 132 children between 3 to 8 years participated in this study, including vocabulary delayed children $(\mathrm{N}=34)$ and typically developing children $(\mathrm{N}=98)$. Participants completed $\mathrm{SL}$ tasks which were composed of three exposure conditions, and Quick incidental learning (QUIL) tasks to tap the novel word learning ability. Results: The VD group score was significantly lower than the TD group in the explicit condition of the auditory statistical learning task, and there was a significant correlation between QUIL and SL_auditory (implicit*2) only in the TD group. Conclusion: These results may explain that the TD group was ready to accept the explicit cues for learning as a domain-specific (auditory) benefit, and their auditory SL ability can be closely linked to vocabulary abilities. The current study suggests one possibility; that the VD group can increase the statistical learning ability through double auditory exposures. The novel quick incidental learning in the TD group was supported by the statistical learning, but this was not seen in the VD group.

Keywords: Statistical learning, Implicit and explicit, Auditory and visual, Vocabulary delay
Statistical learning refers to the processing ability that allows an individual to to automatically and implicitly learn rules or patterns that exist in the environment (Kim, Seithz, Feenstra, \& Shames, 2009). In other words, it is an unconscious cognitive process that extracts repeated rules or patterns from a given sensory environment without direct instruction (Aslin \& Newport, 2012; TurkBrowne, 2012). This ability is innate and is known to play an important role in promoting language development, including the acquisition of the phonological category of the mother's language
(Maye, Werker, \& Gerken, 2002; McMurray, Aslin, \& Toscano, 2009; Newport \& Aslin, 2004; Perruchet \& Pacton, 2006; Teinonen, Fellman, Näätänen, Alku \& Huotilainen, 2009). Children can implicitly detect word boundaries (Conway \& Christiansen, 2001; Evans, Saffran, \& Robe-Torres, 2009; Lany \& Gómez, 2008; Saffran, Johnson, Aslin, \& Newport, 1999) and extract grammatical structures (Newport \& Aslin, 2004; Peña, Bonatti, Nespor, \& Mehler, 2002; Saffran, 2002) from adult's continuous fluent speech. Despite being infants, they are sensitive to linguistic stimuli and can 
discover relationships and rules between the numerous stimuli that exist in language stimulation. In this process, statistical learning plays an important role in encoding linguistic information through listening to sequential fluent speech (Conway \& Christianen, 2001; Lany \& Gomez, 2008).

According to prior research, the statistical learning ability in children with specific language impairment (SLI) is reported to be more domain-generally inefficient than typically developing (TD) peers (Erickson \& Thiessen, 2015; Evans et al., 2009). The domaingeneral perspective means that the learning mechanism is applied to a wide range of areas, and it is a view that holds that different domains (auditory, visual, and motor abilities, etc.) are all collaborative with each other in vocabulary acquisition. On the other hand, a domain-specific perspective holds that certain abilities are independent of each other when learning. For example, this perspective supports that the visual domain and the auditory domain function separately.

Evans et al. (2009) examined the statistical learning of children with SLI and hypothesized that if there is a domain-general deficiency in implicit learning ability of children with SLI, then children with SLI will show poor learning under both speech and nonspeech conditions. They identified whether children with SLI require more exposure than their peers to discover word boundaries. Their results showed that TD children scored greater than 50\% during both 21-minute and 42-minute exposure conditions, and this performance was also significantly related to lexical ability. On the other hand, children with SLI showed a performance scored $50 \%$ (just picking one of the two buttons) under 21-minute exposure condition, while TD children significantly outperformed the children with SLI. In the 42-minute exposure condition, both groups scored more than $50 \%$, and children with SLI were able to show a significant correlation between statistical learning ability and receptive vocabulary in the 42-minute exposure condition (Evans et al., 2009). These results suggested that the children with SLI exhibit inefficient statistical learning skills compared to their peers, and that they need more exposure to vocabulary learning. According to Ulman and Pierpont (2005), children with SLI are vulnerable to such statistical learning because of their deficiency in the procedural learning system.

Yim and Rudoy (2013) used a visual statistical learning task with unnamable shapes as stimuli and an auditory statistical learning task with synonymously structured pure-tones as stimuli to identify whether the language skills of 5 to 13 years old bilingual and monolingual children could explain statistical learning skills. Their results showed that the language skills of the monolingual children's group significantly explained auditory implicit learning ability. This suggests that auditory implicit learning ability is relatively more closely related to language skill than visual implicit learning ability.

If statistical learning ability is very critical for language acquisition and language development, it is necessary to confirm whether enhancing statistical learning ability can improve the children's language skills. In a previous study, a variety of experimental manipulations were used to identify the potential for improvement of statistical learning, such as providing time exposure of implicit learning (Evans et al., 2009) or using explicit methods that are contrary to implicit concepts (Frost, Armstrong, Siegelman, \& Christiansen, 2015; Sun, Zhang, Slusarz, \& Mathews, 2007). Gray (2003) reported that children with SLI require more exposure than TD children to find phonological, semantic, and syntactic information to learn new words.

As shown above, there have been various prior studies related to statistical learning; mainly targeting SLI children (Evans et al., 2009; Lammertink, Boersma, Wijnen, \& Rispens, 2017; MainelaArnold \& Evans, 2014), but few studies of children with vocabulary delay (VD) have been conducted. Since it has been reported that children could learn novel words more efficiently through statistical learning ability in the early stages of word acquisition (Yu, 2008), it is necessary to explore whether the statistical learning skills useful for vocabulary acquisition can be improved for children. Therefore, the present study investigated whether children with and without vocabulary delay (VD) show differences in performance on statistical learning (SL) tasks. The tasks consist of implicit, implicit ${ }^{\star}$, and explicit conditions with visual and auditory domains for verifying the improvement possibility of SL abilities and comparing the SL enhancement conditions of the VD and TD groups. Also, we explored the relationship among the SL, the receptive and expressive vocabulary test (REVT; Kim, Hong, Kim, Jang, \& Lee, 2009), and quick incidental learning (QUIL). 


\section{METHODS}

\section{Participants}

One-hundred thirty-two children participated in this study, with 34 vocabulary delayed children (VD), and 98 typically developing (TD) children aged 3-8 years old.

The TD group who participated in this study were reported as (1) normal cognition, language, and physical abilities by parents or teachers, (2) K-ABC (Moon \& Byun, 2003) non-verbal cognitive test results of 85 points (-1 SD) or higher, (3) REVT (Kim et al., 2009) receptive and expressive vocabulary scores were all in the normal range (-1 SD), and (4) no history of visual and hearing impairment, and emotional behavioral disorders or neurological disorders.

The VD group in this study were reported (1) in the normal cognitive and physical abilities by parents and teachers, (2) K-ABC (Moon \& Byun, 2003) non-verbal cognitive test results of 85 points (-1 SD) or higher, (3) REVT (Kim et al., 2009) receptive and expressive vocabulary scores are all less than -1.5 SD based on their age, and (4) no history of visual and hearing impairment, and emotional behavioral disorders or neurological disorders. Sampling of the study subjects was conducted at daycare center or kindergarten in Seoul and Gyeonggi area.

All subjects were native speakers of Korean and reported no history of a hearing or sight loss, other neurological disorders, or intellectual disability at the time of testing. The age difference between the two groups was not significant except for one occurrence in condition 2 (implicit ${ }^{\star} 2$ ). The Kaufman Assessment Battery for Children (K-ABC; Moon \& Byun, 2003) was used to measure nonverbal IQ. Both groups were confirmed as being within the nor- mal range in their nonverbal IQ despite the significant differences between the groups in condition 3 (explicit) $(p<.05)$. The Receptive and Expressive Vocabulary Test (REVT; Kim et al., 2009) scores of the standardized test were significantly lower for the VD group in all conditions $(p<.01)$. All participants of the VD and TD groups completed QUIL and SL tasks, which consisted of three exposure conditions (implicit, implicit ${ }^{\star} 2$, explicit) with two modalities (visual and auditory), and each of the three exposure condition groups was randomly assigned. All children were assigned to only one condition of three exposure conditions. The non-standardized word learning test, quick incidental learning (QUIL) score was also significantly lower in the VD than the NL (Normal Language) group in condition 1 (implicit) and 2 (implicit $\left.{ }^{\star} 2\right)(p<.05)$. Table 1 summarizes the descriptive statistics of the two groups.

\section{Materials}

\section{Quick incidental learning (QUIL)}

The QUIL is a task to measure novel word learning skills and tap the fast-mapping abilities, with a total of 10 target vocabulary words embedded in each 5-minute animation video (camera story, TV story). The researcher encouraged the child to watch the animation comfortably without any instructions. As soon as the animation video was finished, the child would choose the picture that corresponds to the target vocabulary out of the four pictures to identify if they had learned the target vocabulary. The target vocabularies included four from the camera story ('Naguda', 'Dubi', 'Tapada', 'Gabaeda'), and six from the TV story ('Nottae', 'Bineoda', 'Mekku', 'Hano', 'Ppomaeda', 'Pucha').

Table 1. Participants' characteristics in each condition

\begin{tabular}{|c|c|c|c|c|c|c|c|c|c|}
\hline & \multicolumn{3}{|c|}{ Condition 1} & \multicolumn{3}{|c|}{ Condition 2} & \multicolumn{3}{|c|}{ Condition 3} \\
\hline & $\mathrm{TD}(\mathrm{N}=35)$ & $\operatorname{VD}(N=15)$ & $F$ & $\mathrm{TD}(\mathrm{N}=35)$ & $\operatorname{VD}(\mathrm{N}=14)$ & $F$ & $\mathrm{TD}(\mathrm{N}=35)$ & $\operatorname{VD}(\mathrm{N}=14)$ & $F$ \\
\hline Age (months) & 70.43 (8.85) & $67.27(10.15)$ & 1.228 & $68.63(4.94)$ & 72.93 (8.54) & $4.890^{*}$ & 69.86 (7.69) & $69.14(10.26)$ & .071 \\
\hline Nonverbal IO & 113.54 (15.62) & $107.07(12.71)$ & 2.002 & $109.77(10.60)$ & $107.36(9.21)$ & .556 & $109.49(10.48)$ & $100.43(10.65)$ & $7.40^{* *}$ \\
\hline REVT_Eb & 76.71 (12.04) & 53.07 (19.13) & $28.055^{* *}$ & 74.71 (9.52) & 66.00 (9.79) & $26.095^{* *}$ & 73.57 (8.21) & 54.50 (16.74) & $28.818^{* *}$ \\
\hline REVT-R ${ }^{b}$ & $68.57(12.73)$ & $47.87(12.72)$ & $27.784^{* *}$ & $68.11(9.90)$ & 51.57 (11.09) & $8.244^{* *}$ & $68.40(10.65)$ & $47.79(16.72)$ & $26.670^{* *}$ \\
\hline QUIL" & 50.00 (19.10) & 34.67 (18.47) & $.012^{*}$ & 50.57 (17.98) & 39.29 (14.92) & $4.312^{*}$ & 44.57 (17.21) & 40.71 (16.85) & .508 \\
\hline
\end{tabular}

Values are presented as mean (SDs).

Condition 1 = Implicit; Condition 2= Implicit*2; Condition 3=Explicit; VD = children with Vocabulary Delay; TD= Typically Developing children.

a'Korean Kaufman Assessment Battery for Children (Moon \& Byeon, 2003), 'Receptive \& Expressive Vocabulary Test (Kim, Hong, Kim, Jang, \& Lee, 2010), 'Quick Incidental Learning (Yang, Yim, Kim, \& Han, 2013).

${ }^{*} p<.05,{ }^{* *} p<.01$. 


\section{Auditory statistical learning (ASL)}

The auditory statistical learning task is for identifying whether the participants can find the rule or pattern while listening to continuous pure tones. In this research, we used the tasks designed by Yim et al. (2016), who revised the tasks created Yim and Windsor (2010). The auditory stimuli consist of 9 tones (Set 1: A, F\#, F/ Set 2: E, B, C/ Set 3: D, C\#, G) in one octave and they are categorized into 3 different sets. The tasks are divided into learning and testing sessions (Yim et al., 2016).

During the learning session, subjects continuously listen to 3 sets of randomly arranged auditory stimuli (pure tones) for 170 seconds. In the test session, the researcher presents two sets of auditory stimuli for each item. The auditory stimuli consists of two types: one that was revealed during the learning session and an unfamiliar novel sound to the subjects that was not presented in the learning session. For the group in condition 1, the examiner does not explain the rules of auditory stimuli before the test session and the subjects listen to the stimuli once (for 170 seconds). For the group in condition 2, the examiner does not explain the rules of auditory stimuli before the test session as well, but the subjects listen to the stimuli twice (for 340 seconds). For the group in condition 3 , the subjects receive the explicit instructions at the beginning of the test session after the learning session is completed and then listen to the stimuli once (for 170 seconds). The researcher will instruct, "Listen carefully, you will be able to hear some sounds with the other sounds and there are rules as follows (Some daily auditory sound are presented in sequence, such as a doorbell, a car horn, and then a vacuum cleaner sound sets). Listen carefully to the order in which the sounds are heard. I will ask you later."

After the learning session, the test session starts immediately. During the testing session, three groups are all instructed to choose a familiar pure tone between the two sets of auditory stimuli.

\section{Visual statistical learning (VSL)}

Visual statistical learning tasks are conducted in the same manner as the auditory statistical learning tasks. These tasks use visual stimuli. The visual stimuli consist of 3 sets of 9 figures. The subjects would see each stimulus for 1 second and there would be 0.25 -second pause between visual stimulus. Tasks are divided into learning sessions and testing sessions. During the learning sessions, subjects would watch continuous visual stimuli for 4 minutes and 30 seconds through the computer monitor. After the learning session, a researcher would present two visual sets of stimuli: one that was revealed during the learning session and a completely different combination from what was previously presented. After the session, the subject is then asked to choose the more familiar picture (visual stimuli) when presented with a choice (Yim et al., 2016).

Similar to the tasks of auditory implicit learning, the researcher would not explain the rules of visual stimuli before the test session in condition 1. For the group in condition 2, the researcher will not explain the rules of visual stimuli before the test session as well, but the subjects will watch the stimuli twice. For the group in condition 3 , the subjects receive the explicit instructions that there will be a test session after the learning session, and they watch the stimuli once. The instructions would be the same as follows. "Now, look at this picture carefully. Those figures will appear and there will have some rules. Some figures always come together (the subjects are not presented with real target figures. They watch triangles, squares, and circles as example). First, the triangle, then square and finally the circle appears. Watch carefully what kinds of figures appear together. I will ask you later."

\section{Procedures and Data Analyses}

After the screening test with K-ABC (Moon \& Byun, 2003) measuring nonverbal IQ and REVT (Kim et al., 2009) measuring vocabulary, the experimental tasks of this study were immediately conducted: QUIL (quick incidental learning) and SL (statistical learning). The VD and TD group were randomly assigned to three groups (Implicit, Implicit ${ }^{\star}$, and explicit). All children were tested in the identical order. The total number of items for each auditory and visual SL task was twenty-four (In each question, children acquired 0 points if wrong and 1 point if correct), and was converted to a \% score (e.g., children's score/24 [total score] $\left.{ }^{\star} 100\right)$. The reliability of these SL tasks was about $98.3 \%$ when two doctoral students majoring in communication disorders calculated the reliability between evaluators (inter-rater reliability) using a sample of $30 \%$ randomly selected from the data of participants.

Statistical analysis was conducted according to research questions. (1) An ANCOVA (nonverbal IQ and age as covariates) was conducted to examine whether the difference in performance be- 
tween the VD and TD groups was significant in SL tasks (auditory and visual), and (2) One-sample $t$-test was conducted to identify whether the performance was 50\% (chance level) or higher. (3) Pearson's correlation coefficient was performed to find out whether the correlation between SL, vocabulary, and QUIL of each group was significant. Simple linear regression was conducted to see if SL could make a significant contribution to vocabulary learning if the correlation (Pearson's correlation coefficient) between SL, vocabulary, and QUIL was significant.

\section{RESULTS}

\section{Group Differences in Statistical Learning Depending on Modality and Exposure Condition}

Our primary research question was to examine whether children with VD would underperform compared to the TD children in statistical learning (SL). Figure 1 shows the performance of both groups for the SL task. An ANCOVA (nonverbal IQ and age as covariates) was conducted with two groups (TD / VD) and the three exposure conditions (implicit/ implicit ${ }^{\star}$ / explicit) as independent variables and between-subject factors, and the percentage of accurate responses on auditory and visual SL scores served as dependent measures.

The VD group showed a statistically significant difference in the auditory SL task compared to the TD group $\left(F_{(1,124)}=4.412\right.$, $p=.038$ ), but the difference was not significant in the visual SL $\operatorname{task}\left(F_{(1,124)}=1.906, p=.170\right)$. In the auditory SL task, the VD group was $49.72(\mathrm{SE}=1.65)$ and received a significantly lower score than

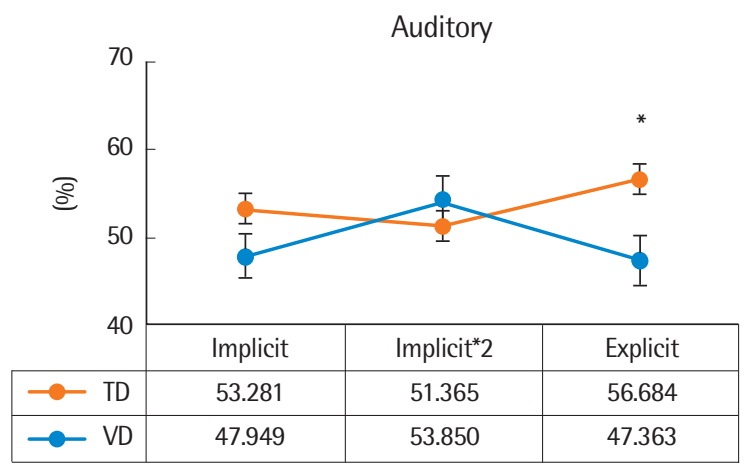

the TD group, which was $53.78(\mathrm{SE}=.948)$. In the visual SL task, the VD group was $50.80(\mathrm{SE}=1.66)$ and the TD group with 53.47 $(\mathrm{SE}=.951)$. In addition, the main effect of the three exposure conditions was not valid and the secondary interaction between group * condition was significant in the auditory domain $(p=.045)$ but not in the visual domain ( $p=.938)$.

The children in condition 1 who performed the original version of the statistical learning task did not exhibit any significant difference between the VD and TD groups in the auditory SL task $\left(F_{(1,44)}=3.175, p>.05\right)$, nor in the visual SL task $\left(F_{(1,44)}=.971, p>.05\right)$. In condition 2 , where the original version of the task was exposed twice, the performance difference between the VD and TD children was not significant in the auditory SL task $\left(F_{(1,34)}=.438, p>.05\right)$ or in the visual SL task $\left(F_{(1,34)}=.989, p>.05\right)$. However, even if there were no statistically significant differences, the performance of the VD group tended to be higher than the TD group as the VD group received 54.27 $(\mathrm{SE}=3.93)$ and the $\mathrm{TD}$ group received 51.26 $(\mathrm{SE}=2.15)$ in the auditory SL task. In condition 3, where the explicit instruction is provided, the VD group with $46.27(\mathrm{SE}=2.36)$ showed significantly lower performance $\left(F_{(1,42)}=15.134, p=.000\right)$ than the TD group with $57.05(\mathrm{SE}=1.37)$ in the auditory SL tasks. In the visual SL task, the VD group also showed lower performance with 52.88 $(\mathrm{SE}=3.09)$ compared to the TD group with $54.60(\mathrm{SE}=1.80)$, but was not statistically significant $\left(F_{(1,42)}=.225, p=.638\right)$.

\section{Chance-level Test in Statistical Learning for Each Group}

The statistical learning task of this study was divided into a practice session and a test session. In the test session, a forced-choice

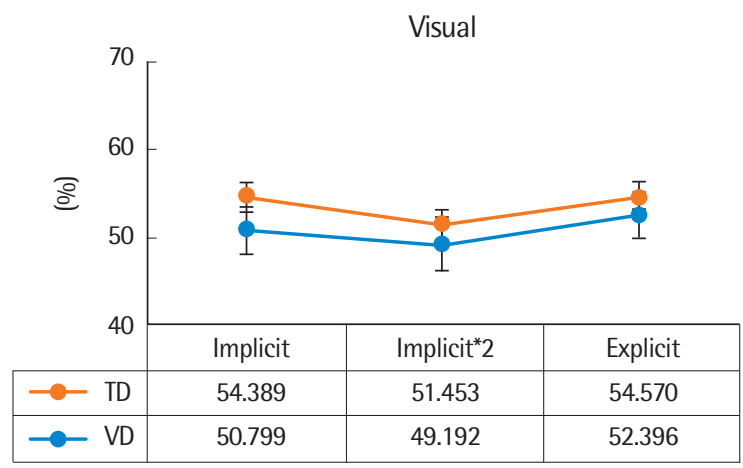

Figure 1. Accuracy (\%) of statistical learning for group, and exposure condition in each domain. VD=children with Vocabulary Delay; $T D=$ Typically Developing children. 
Table 2. One-sample $t$-test for each group in each condition of statistical learning

\begin{tabular}{|c|c|c|c|c|c|}
\hline \multirow{3}{*}{ Domain } & \multirow{3}{*}{$\begin{array}{l}\text { Exposure } \\
\text { condition }\end{array}$} & \multicolumn{4}{|c|}{ Test value $=50$} \\
\hline & & \multicolumn{2}{|c|}{ VD } & \multicolumn{2}{|c|}{ TD } \\
\hline & & $t$ & $p$ & $t$ & $p$ \\
\hline \multirow[t]{3}{*}{ Auditory } & Implicit & .357 & $>.05$ & 2.018 & $>.05$ \\
\hline & Implicit*2 & 2.153 & $>.05$ & 1.331 & $>.05$ \\
\hline & Explicit & -.128 & $>.05$ & 4.510 & $<.01^{* * *}$ \\
\hline \multirow[t]{3}{*}{ Visual } & Implicit & .041 & $>.05$ & 2.446 & $<.05^{*}$ \\
\hline & Implicit*2 & -1.543 & $>.05$ & .961 & $>.05$ \\
\hline & Explicit & -1.016 & $>.05$ & 3.180 & $<.01^{* *}$ \\
\hline
\end{tabular}

$\mathrm{VD}=$ children with Vocabulary Delay; $\mathrm{TD}=$ Typically Developing children. ${ }^{*} p<.05,{ }^{* *} p<.01$.

Table 3. The correlation coefficients among Statistical learning conditions, vocabulary, and QUIL in the TD group

\begin{tabular}{lcccccccc}
\hline $\begin{array}{l}\text { Variables } \\
\text { of interest }\end{array}$ & M & SD & SL_A1 & SL_A2 & SL_A3 & SL_V1 & SL_V2 & SL_V3 \\
\hline REVT_R & 68.36 & 11.052 & .034 & -.049 & -.094 & -.120 & .029 & .314 \\
REVT_E & 75.00 & 10.036 & .122 & -.047 & -.010 & .086 & -.111 & .289 \\
QUIL & 48.38 & 18.141 & .218 & $.352^{*}$ & .156 & -.057 & -.223 & .020 \\
\hline
\end{tabular}

TD = Typically Developing children; SL_A1 = Auditory Implicit; SL_A2=Auditory Implicit* ${ }^{*}$; SL_A3=Auditory Explicit; SL_V1 = Visual Implicit; SL_V2=Visual Implicit*2; SL_V3=Visual Explicit; Receptive \& Expressive Vocabulary Test (Kim, Hong, Kim, Jang, \& Lee, 2010); Quick Incidental Learning (Yang, Kim, Han, \& Yim, 2013). ${ }^{*} p<.05$.

test was performed to select the more familiar one of two items. According to the previous studies, children showed true learning performance when they achieved 50\% accuracy or higher based on the chance level (Saffran et al., 1999). Therefore, one sample $t$ test was conducted with the test value at 50 .

As a result, there was no significant difference between the chance level in the VD group's in all domain and exposure conditions $(p>.05)$. In contrast, the TD group performed significantly higher than $50 \%$ in the explicit (condition 3) of the auditory task $\left(t_{(34)}=\right.$ $4.510, p<.05)$ and they performed significantly higher than $50 \%$ in the implicit (condition 1) $\left(t_{(34)}=2.446, p<.05\right)$ and explicit (condition 3) $\left(t_{(34)}=3.180, p<.05\right)$ in the visual task. The detailed results are presented in Table 2.

\section{Correlation and Regression}

Although no detailed conditions of statistical learning showed a significant correlation with the receptive vocabulary (REVT-R) and the expressive vocabulary (REVT-E) in the TD group ( $p>.05)$,
Table 4. The correlation coefficients among Statistical learning conditions, vocabulary, and QUIL in the VD group

\begin{tabular}{lcccccccc}
\hline $\begin{array}{c}\text { Variables } \\
\text { of interest }\end{array}$ & M & SD & SL_A1 & SL_A2 & SL_A3 & SL_V1 & SL_V2 & SL_V3 \\
\hline REVT_R & 49.05 & 13.477 & .007 & -.008 & .122 & .097 & -.272 & .286 \\
REVT_E & 57.74 & 16.503 & -.151 & .088 & .160 & .234 & -.504 & .014 \\
QUIL & 38.14 & 16.656 & .114 & .190 & -.415 & -.183 & -.527 & .028 \\
\hline
\end{tabular}

VD = children with Vocabulary Delay; SL_A1 = Auditory Implicit; SL_A2 = Auditory Implicit*2; SL_A3=Auditory Explicit; SL_V1 = Visual Implicit; SL_V2=Visual Implicit*2; SL_V3=Visual Explicit; Receptive \& Expressive Vocabulary Test (Kim, Hong, Kim, Jang, \& Lee, 2010); Quick Incidental Learning (Yang, Kim, Han, \& Yim, 2013).

it showed significant correlation with condition 2 (implicit $\left.{ }^{\star} 2\right)$ in the auditory domain and quick incidental learning (QUIL) $(r=.352$, $p<.05)$. A simple linear regression was performed to confirm the importance of SL_A2 (Statistical Learning_Auditory Implicit ${ }^{\star} 2$ ) to QUIL, and it was found that SL_A2 had a $12.4 \%$ explanatory power for QUIL $\left(F_{(1,33)}=4.679, p<.05, \mathrm{R}^{2}=.124\right)$.

On the other hand, the VD group did not show any SL conditions that showed significant correlation with receptive vocabulary (REVT-R), expressive vocabulary (REVT-E), and quick incidental learning (QUIL) capabilities. The detailed results are presented in Tables 3 and 4.

\section{DISCUSSION \& CONCLUSION}

The purpose of this study was to investigate the difference in the performance of statistical learning between VD and TD children and to examine the possibility of improving the statistical learning ability. We divided the conditions into three types: implicit, implicit $^{\star} 2$, and explicit; depending on whether the instruction is provided or not. We also divided the conditions into visual and auditory categories to see if statistical learning task performance appears to be domain-general or domain-specific. In addition, we tried to examine whether each of the conditions for statistical learning has a significant correlation with the receptive vocabulary (REVT-R), expressive vocabulary (REVT-E), or quick incidental learning (QUIL).

Although the differences in performance between the VD and TD groups were not significant in the visual task, they were significant in the auditory task. The learning deficits of VD children were found only in the auditory domain rather than in both auditory 
and visual domains. Therefore, visual and auditory domain may be independent, and sensory modalities need to be considered when evaluating learning abilities of children with VD (Conway \& Christiansen, 2005, 2009). However, the difference in statistical learning according to domains may have different results depending on the type of stimulus and the difficulty of the task, so these results should be interpreted carefully. In particular, the difference between groups in the visual task in this study was not statistically significant, but children with VD tended to receive lower scores than TD children. In addition, typical learners without language impairment were reported to be able to quickly learn grammarlike patterns in the auditory domain (Conway \& Christiansen, 2005). However, the auditory domain benefit only appears to the typical learners rather than the language impaired group, because the VD group performed significantly lower in the auditory task compared to the TD group in this study.

As a result of examining the exposure condition of statistical learning tasks or task performance, a significant difference was not found in the auditory and visual performance of the VD and TD group in implicit (condition 1) and implicit ${ }^{\star}$ (condition 2). There was no significant difference between VD and TD children in the auditory implicit learning of this study, which was inconsistent with previous study results (Evans et al., 2009; Lammertink et al., 2017). The characteristics of the auditory stimuli of this study were composed of pure-tones, which were difficult to name. Therefore, it is inferred that the vocabulary knowledge did not have a significant benefit for the TD children's task performance.

Although there was no statistically significant difference, the VD group tended to score higher than the TD group in the auditory task with double exposure, suggesting that it might be beneficial to increase the duration of auditory stimuli provided to the VD group (Evans et al., 2009; Rice, Buhr, \& Oetting, 1992). Children with VD may require relatively more exposure (double exposure) for learning than TD children. On the other hand, the TD children were able to learn with the original exposure condition. In the TD group, exposure for learning was already enough in its original condition, and further exposure time was not necessarily required for optimal learning. It is also possible to interpret that more exposure time than necessary can lower attentional concentration. Gray (2003) also reported that in terms of word learning, children with SLI needed to listen to novel words twice as many times as their peers. In condition 1 and condition 2, there was no significant difference in performance between the two groups in both auditory and visual tasks. However, in condition 3 with explicit instruction, the auditory performance of the VD group was significantly lower than the TD group. The VD children showed significantly lower performance than TD children in the auditory task, whereas similar performance in the visual task showed that the auditory condition was more difficult than the visual condition as shown in previous studies (Arciuli, 2018; Evans et al., 2009; Lammertink et al., 2017). This difficulty of processing auditory information puts children in more challenging situations to learn new vocabulary auditorily in the early stages of language development. In addition, in the explicit condition of the auditory task, TD children clearly showed a learning effect and obtained high scores, whereas the children with VD did not show any learning effect. In other words, the TD children understood and performed tasks when explicitly instructed of the changing condition, whereas under the same condition, the children with VD did not reach the level of performance of the TD children. When required to pay conscious attention to the verbal information during the instruction, the VD group may be expected to have difficulty in learning efficiently because the information exceeds the learner's attention capacity (Cowan et al., 2005; Lavie, 2005).

As a result of verifying the actual learning of the children by performing more than chance level in the statistical learning tasks of the study, the VD group showed a performance which was not significantly different from the chance level of 50 points under any condition, but the TD group showed a performance that was more than the chance level in auditory explicit (SL_A3), visual implicit (SL_V1) and visual explicit (SL_V3) conditions. The TD group showed that learning had been performed more significantly in the explicit conditions under domain-general (Swisher, Restrepo, Plante, \& Lowell, 1995). Also, the fact that in the visual task, they performed above the chance level in condition 1 with shorter exposure than the condition 2, suggests that more exposure may not necessarily be beneficial to children in the TD group (Evans et al., 2009; Gray, 2003; Rice et al., 1992).

In order to answer our research question, we tried to discover the relationship between each condition of statistical learning and 
the receptive vocabulary (REVT-R), the expressive vocabulary (REVT-E), the quick incidental learning (QUIL), and to clarify whether the contribution of statistical learning to word learning was significant. The VD group did not show any significant relationship but SL_A2 and QUIL showed a significant correlation in the TD group and SL_A2 explained QUIL. Statistical learning is regarded to be critical for word learning (Estes, Evans, Alibali, \& Saffran, 2007; Mirman, Magnuson, Estes, \& Dixon, 2008).

The VD group did not link the statistical learning to efficient word learning. Previous studies suggested that children with VD were less effective in suppressing competing representations and did not focus attention on the target, resulting in inefficient or slow word learning (McMurray, Samuelson, Lee, \& Tomblin, 2006; Mainela-Arnold, Evans, \& Coady, 2008; Tomblin, Mainela-Arnold, \& Zhang, 2007). Another possibility was that the VD group did not adequately store the detailed phonological forms of novel target words (Mainela-Arnold et al., 2008). According to the Ullman's procedural learning deficit hypothesis of SLI, word learning is supported by declarative memory systems, not procedural memory, so infants can begin to find a word in continuous speech even the earliest stages (Evans et al., 2009; Saffran \& Estes, 2006). On the other hand, the TD group was ready to detect word boundaries in the presented information, and this ability seemed to be related to word learning (Evans et al., 2009). The TD children could listen to the continuous speech and track the transition probability (Saffran, Newport, Aslin, Tunick, \& Barrueco, 1997).

In conclusion, the current study suggests the possibility that children with VD can increase their statistical learning ability through double auditory exposures, and the novel quick incidental learning in the TD group was supported by the statistical learning, but this was not seen in the VD group. Future studies should be able to suggest ways to link statistical learning with word learning as well as efforts to improve the statistical learning abilities of children with VD.

\section{REFERENCES}

Arciuli, J. (2018). Reading as statistical learning. Language, Speech, and Hearing Services in Schools, 49(3S), 634-643.

Aslin, R. N., \& Newport, E. L. (2012). Statistical learning from acquiring spe- cific items to forming general rules. Current Directions In Psychological Science, 21(3), 170-176.

Conway, C. M., \& Christiansen, M. H. (2001). Sequential learning in nonhuman primates. Trends in Cognitive Sciences, 5(12), 539-546.

Conway, C. M., \& Christiansen, M. H. (2005). Modality-constrained statistical learning of tactile, visual, and auditory sequences. Journal of Experimental Psychology: Learning, Memory, and Cognition, 31(1), 24-39.

Conway, C. M., \& Christiansen, M. H. (2009). Seeing and hearing in space and time: effects of modality and presentation rate on implicit statistical learning. European Journal of Cognitive Psychology, 21(4), 561-580.

Cowan, N., Elliott, E. M., Saults, J. S., Morey, C. C., Mattox, S., Hismjatullina, A., \& Conway, A. R. (2005). On the capacity of attention: its estimation and its role in working memory and cognitive aptitudes. Cognitive Psychology, 51(1), 42-100.

Erickson, L. C., \& Thiessen, E. D. (2015). Statistical learning of language: theory, validity, and predictions of a statistical learning account of language acquisition. Developmental Review, 37, 66-108.

Estes, K. G., Evans, J. L., Alibali, M. W., \& Saffran, J. R. (2007). Can infants map meaning to newly segmented words? Statistical segmentation and word learning. Psychological Science, 18(3), 254-260.

Evans, J. L., Saffran, J. R., \& Robe-Torres, K. (2009). Statistical learning in children with specific language impairment. Journal of Speech, Language, and Hearing Research, 52(2), 321-335.

Frost, R., Armstrong, B. C., Siegelman, N., \& Christiansen, M. H. (2015). Domain generality versus modality specificity: the paradox of statistical learning. Trends in Cognitive Sciences, 19(3), 117-125.

Gray, S. (2003). Word-learning by preschoolers with specific language impairment: what predicts success?. Journal of Speech, Language, and Hearing Research, 46(1), 56-67.

Kim, Y., Hong, K., Kim, K., Jang, H., \& Lee, J. (2009). Receptive and Expressive Vocabulary Test (REVT). Seoul: Seoul Community Rehabilitation Center.

Kim, R., Seitz, A., Feenstra, H., \& Shams, L. (2009). Testing assumptions of statistical learning: is it long-term and implicit?. Neuroscience letters, 461(2), $145-149$.

Lammertink, I., Boersma, P., Wijnen, F., \& Rispens, J. (2017). Statistical learning in specific language impairment: a meta-analysis. Journal of Speech, Language, and Hearing Research, 60(12), 3474-3486.

Lany, J., \& Gómez, R. L. (2008). Twelve-month-old infants benefit from prior experience in statistical learning. Psychological Science, 19(12), 1247-1252. Lavie, N. (2005). Distracted and confused?: Selective attention under load. 
Trends in Cognitive Sciences, 9(2), 75-82.

Mainela-Arnold, E., \& Evans, J. L. (2014). Do statistical segmentation abilities predict lexical-phonological and lexical-semantic abilities in children with and without SLI?. Journal of Child Language, 41(2), 327-351.

Mainela-Arnold, E., Evans, J. L., \& Coady, J. A. (2008). Lexical representations in children with SLI: evidence from a frequency-manipulated gating task. Journal of Speech, Language, and Hearing Research, 51(2), 381-393.

Maye, J., Werker, J. F., \& Gerken, L. (2002). Infant sensitivity to distributional information can affect phonetic discrimination. Cognition, 82(3), B101B111.

McMurray, B., Aslin, R. N., \& Toscano, J. C. (2009). Statistical learning of phonetic categories: insights from a computational approach. Developmental Science, 12(3), 369-378.

McMurray, B., Samuelson, V., Lee, S., \& Tomblin, J. B. (2006). Eye movements reveal the time course of spoken word recognition in normal and languageimpaired adolescents. In poster presented at the Symposium on Research in Child Language Disorders, Madison, WI.

Mirman, D., Magnuson, J. S., Estes, K. G., \& Dixon, J. A. (2008). The link between statistical segmentation and word learning in adults. Cognition, 108(1), 271-280.

Moon, S. B., \& Byun, C. J. (2003). Korean Kaufman assessment battery for children (K-ABC). Seoul: Hakjisa.

Newport, E. L., \& Aslin, R. N. (2004). Learning at a distance I. Statistical learning of non-adjacent dependencies. Cognitive Psychology, 48(2), 127-162.

Peña, M., Bonatti, L. L., Nespor, M., \& Mehler, J. (2002). Signal-driven computations in speech processing. Science, 298(5593), 604-607.

Perruchet, P., \& Pacton, S. (2006). Implicit learning and statistical learning: one phenomenon, two approaches. Trends in Cognitive Sciences, 10(5), 233-238.

Rice, M. L., Buhr, J., \& Oetting, J. B. (1992). Specific-language-impaired children's quick incidental learning of words: the effect of a pause. Journal of Speech, Language, and Hearing Research, 35(5), 1040-1048.

Saffran, J. R. (2002). Constraints on statistical language learning. Journal of Memory and Language, 47(1), 172-196.

Saffran, J. R., \& Estes, K. G. (2006). Mapping sound to meaning: connections between learning about sounds and learning about words. Advances in
Child Development and Behavior, 34, 1-38.

Saffran, J. R., Johnson, E. K., Aslin, R. N., \& Newport, E. L. (1999). Statistical learning of tone sequences by human infants and adults. Cognition, 70(1), 27-52.

Saffran, J. R., Newport, E. L., Aslin, R. N., Tunick, R. A., \& Barrueco, S. (1997). Incidental language learning: listening (and learning) out of the corner of your ear. Psychological Science, 8(2), 101-105.

Sun, R., Zhang, X., Slusarz, P., \& Mathews, R. (2007). The interaction of implicit learning, explicit hypothesis testing learning and implicit-to-explicit knowledge extraction. Neural Networks, 20(1), 34-47.

Swisher, L., Restrepo, M. A., Plante, E., \& Lowell, S. (1995). Effect of implicit and explicit "rule" presentation on bound-morpheme generalization in specific language impairment. Journal of Speech, Language, and Hearing Research, 38(1), 168-173.

Teinonen, T., Fellman, V., Näätänen, R., Alku, P., \& Huotilainen, M. (2009). Statistical language learning in neonates revealed by event-related brain potentials. BMC Neuroscience, 10(1), 13-21.

Tomblin, J. B., Mainela-Arnold, E., \& Zhang, X. (2007). Procedural learning in adolescents with and without specific language impairment. Language Learning and Development, 3(4), 269-293.

Turk-Browne, N. B. (2012). Statistical learning and its consequences. Nebraska Symposium on Motivation, 59, 117-146.

Ullman, M. T., \& Pierpont, E. I. (2005). Specific language impairment is not specific to language: the procedural deficit hypothesis. Cortex, 41(3), 399433.

Yim, D., Kwak, A., Lee, Y., Han, W., Lee, J., Chun, S., ..., \& Han, J. (2016). Statistical learning in children with primary language impairment. Journal of Speech-Language \& Hearing Disorders, 25(3), 61-69.

Yim, D., \& Rudoy, J. (2013). Implicit statistical learning and language skills in bilingual children. Journal of Speech, Language, and Hearing Research, 56(1), 310-322.

Yim, D., \& Windsor, J. (2010). The roles of nonlinguistic statistical learning and memory in language skill. Korean Journal of Communication \& Disorders, 15(3), 381-396.

Yu, C. (2008). A statistical associative account of vocabulary growth in early word learning. Language Learning and Development, 4(1), 32-62. 


\section{국문초록}

\section{통계적 학습 능력은 증진될 수 있는가? 어휘발달지연 아동의 통계적 학습 능력 향상 탐색}

임동선 $\cdot$ 양윤희 ${ }^{2}$

${ }^{1}$ 이화여자대학교 대학원 언어병리학과, ${ }^{2}$ 이화여자대학교 특수교육연구소

배경 및 목적: 언어습득에 통계적 학습 능력이 매우 중요하다면, 통계적 학습 능력을 높여서 아동들의 언어 능력을 향상시킬 수 있는지 확인해볼 필요가 있다. 본 연구는 어휘발달지연이 있는 아동과 일반 아동들이 시각적 또는 청각적 영역에서의 암묵적 조건(implicit), 암 묵적 조건이면서 노출을 2 배한 조건(implicit²), 명시적 조건(explicit)으로 나누어진 통계적 학습 과제 수행의 향상에서 차이를 보이는 지, 통계적 학습 능력은 어휘 능력 및 빠른우연학습(Quick incidental learning, QUIL)과 유의한 관련이 있는지를 확인하고자 하였다. 방법: 3-8세의 어휘발달지연 아동 $(\mathrm{N}=34)$ 과 일반 아동 $(\mathrm{N}=98)$, 총 132 명의 아동이 본 연구에 참여하였다. 참여 아동들은 세 가지 노출 조건으로 구성된 통계적 학습 과제와 새로운 어휘 학습 능력을 측정하는 빠른우연학습(QUIL) 과제를 수행하였다. 결과: 청각 통계적 학습 과제의 명시적 조건에서 어휘발달지연 아동 집단의 점수는 일반 아동 집단보다 현저히 낮았고, 일반 아동 집단에서만 빠른우연학 습(QUIL)과 청각 통계적 학습의 암묵적 조건이면서 노출을 2 배한 조건(implicit $\left.{ }^{\star 2}\right)$ 간 유의한 상관이 있었다. 논의 및 결론: 일반 아동 집단은 학습에 대한 명시적 단서를 청각적으로 유익하게 받아들일 준비가 되어 있었고, 청각 통계적 학습 능력은 어휘 능력과 밀접하게 연결될 수 있다고 설명할 수 있다. 현재의 연구는 어휘발달지연 아동 집단이 청각적 노출을 두 배로 늘렸을 때 통계적 학습 능력을 높일 수 있다는 하나의 가능성을 제시한다.

핵심어: 통계적 학습, 암묵적 학습과 명시적 학습, 청각과 시각, 어휘발달지연

\section{참고문헌}

김영태, 홍경훈, 김경희, 장혜성, 이주연 (2009). 수용·표현 어휘력 검사. 서울: 서울장애인종합복지관.

문수백, 변창진 (2003). K-ABC 교육·심리측정도구 (Korean-Kaufman assessment battery for children: K-ABC). 서울: 학지사.

임동선, 곽아람, 이여진, 한우주, 이지혜, 천소연, 이슬기, 한지윤 (2016). 일차성 언어장애 (PLI) 아동의 통계적 학습능력. 언어치료연구, 25(3), 61-69. 임동선, 제니퍼 윈저. (2010). 언어능력에서 비언어정보 통계적 학습과 기억력 역할. 언어청각장애연구, 15(3), 381-396.

\section{ORCID}

임동선(제1저자, 교신저자, 교수 https://orcid.org/0000-0001-8254-9504); 양윤희(공동저자, 연구교수 https://orcid.org/0000-0003-3240-5996) 